\title{
Time Dependent Properties of Concrete: A State of the Art Review
}

\author{
Youkhanna Zayia Dinkha ${ }^{1, *}$, Salim T. Yousif ${ }^{2}$ \\ ${ }^{1}$ Department of Civil Engineering, University of Duhok, Kurdistan Region - Iraq, youkhanna.zayia@uod.ac \\ ${ }^{2}$ Department of Civil Engineering, Al-Qalam University College, Kirkuk, Iraq, salim.yousif@alqalam.edu.iq
}

\begin{abstract}
This work summarizes the prediction models for creep strain taken place in concrete under compression as well as under tension and shear. In literature, many researchers have carried out experimental studies on creep, RILEM has gathered these experimental results within a computerized data bank. This work briefly reviews the most widely used models and can predict observations up to 5000 days assessed by ACI209R-1992 Model, B3 Model, CEB C99 Model, GL 2000 Model, BS 8110 (1985), and AS3600 (1988). Since creep is one of the most important time dependent property of concrete as it increases cracking and harmfully distresses the function, durability, and structural appearances. The objective of this work is to understand the behavior of concrete when creep strain takes place at different ages by incorporating spread sheets which simplify the calculations for engineers when estimating the creep strain for the design purpose. Based on RILEM data bank, most of the studies confirms that GL2000 Model is the closest to the experimental results
\end{abstract}

Keywords: concrete, creep strain, time dependent, prediction models

Received: May 19, 2021 / Accepted: July 29, 2021 / Online: August 7, 2021

\section{INTRODUCTION}

Creep is the increase in strain of a solid object under control stress over time. Different creep strains include basic creep and drying creep. If the concrete has no moisture exchange, only basic creep will happen. The dry creep experienced is due to being allowed to dry while it is under load. The term total creep is used to refer to all kinds of creep strains (basic and dry creeps [1].

The stain due to creep at any time $\varepsilon \mathrm{c}(\mathrm{t})$ can be determined from:

$$
\varepsilon_{c}(t)=\varepsilon(t)-\varepsilon_{e}-\varepsilon_{s h}(t)
$$

Where:

$\varepsilon_{c}(t)=$ strains at any time due to creep

$\varepsilon(\mathrm{t})=$ total observed stain

$\varepsilon_{\mathrm{e}}=$ elastic strain after load application

$\varepsilon_{\text {sh }}(\mathrm{t})=$ strain due to drying shrinkage (for unloaded samples).

\section{EFFECTS OF CREEP}

Creep of concrete can be both a positive and serious problem. On the one hand it is good because it gives some ductility to concrete. In comparison, creep can cause excessive deflections at service loads, which can result in the instability of the arch or shell, cracking, buckling of long columns, and loss of prestress [2]. The deleterious effects of creep are more harmful to non-load-bearing elements such as windows, claddings, and other construction materials than the structure itself [3].

Sometimes, damaged buildings are either restored prior to their planned design life or shut down, creating economic consequences. creep is commonly identified for its alleged negative impact. A significant design factor for structures dealing with toughness, resilience and load capacity are creep rates. The intensity and ultimate magnitude of creep, being used in the design of a reinforced concrete structure, can be measured at different levels, due to the nature of the proposed structure and how well it would be influenced by sensitivity to deformations. In summary, the further susceptible the structure to study, the more rational the cost and sophistication of estimation methods. In cases where only an approximate estimation of creep is needed, design code models are suitable

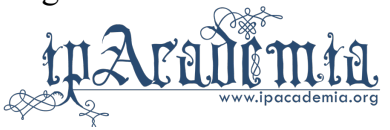


for prediction purposes. Predictions are based on a few parameters, which are defined from the beginning, as the input to the models [4].

\section{ASSUMPTIONS FOR THE DESIGN OF PREDICTION MODELS}

Various standardized tests have been established for measuring the levels of shrinkage and creep in concrete. Following, are the Important simplifying assumptions commonly used in the production of prediction models:

\section{A. Creep and Shrinkage additional}

Identical sets of specimens are randomly selected and put in the same setting for a curing period. A set is not loaded which is used to assess shrinkage, while the other is typically loaded from 20 to 40 percent of the concrete compressive force. Loadinduced strains are the difference between the strains measured on the unloaded specimens and the strains measured on the loaded specimens. Consequently, it is presumed that the creep and shrinkage are distinct. Tests conducted on preserved specimens are used to find creep and the autogenous shrinkage.

\section{B. The linear age model for creep}

Creep may typically be defined as proportional to stress, but the stress applied should be no greater than $40 \%$ of the concrete's compression strength [5]. The response of strain to stress increase is functional at various times could be summed by means of superposition principle when increase and reduction of stress [6], provided strain reversals are excluded (for example, as in relaxation) and temperature and moisture content are kept constant [7-9].

\section{Creep Separation into basic creep and drying creep}

Basic creep is measured on a specimen that is housed in a sealed situation which prevents the leaching of moisture from or to its surroundings. This type of property is independent of the size or shape of the specimen. Drying creep means the remaining strain after deducting the elastic, basic creep and shrinkage strains from overall measured strain on technically identical samples inside a drying environment. The average creep measured for a cross section during drying depends greatly on its size [5].

\section{Differential creep and creep gradients are neglected}

The majority of reported data dealing with creep and shrinkage of cylindrical specimens may be due to the assumption that creep and shrinkage strains are uniform through the specimen cross section, regardless of whether finite element analysis or equivalent linear gradients are used $[8,10]$.

\section{E. Neglect the induced stress during curing phase}

Almost all experiment measure strains from the begin drying. In this estimate, the strains that are mainly caused by concrete shrinkage and autogenous shrinkage are apparently negligible because the creep strains are extremely high at early ages. The assumption become overestimated for restrained swelling when measuring tensile stress, thus making it appropriate basis for design purposes when computing prestress losses and deflections.

\section{PREDICTION MODELS}

\section{A. Criteria for models of prediction}

Several models for the estimation of creep, and total strains under load have been proposed over the past 30 years. Such models are a compromise between reliability and convenience. The committee concludes that a model or models available to engineers with little specialized creep knowledge is one of the primary requirements. Major concerns involve, but are not limited to:

- How straightforward or complicated a model would be and what input data should be requested;

- What information are used for the model evaluation;

- How closely physical phenomena/behavior should be represented by the model.

- To evaluate a model, which statistical techniques are suitable.

There is still no agreement on the information required for the calculation of the time-dependent concrete properties; whether the mechanical properties of the concrete specified at the time of design should be adequate, or whether the proportions of the mixture are also required. At the very least, the committee suggest that the following information should be included in shrinkage and creep models:

- The concrete will be described either by the compositions of the concrete or its mechanical properties including its strength or elasticity;

- $\quad$ Relative humidity for ambient;

- $\quad$ Age of concrete at loading;

- $\quad$ Drying duration;

- Loading duration;

- Size of specimen.

Models must also:

- $\quad$ Permit the substitution of the values for test of modulus of elasticity and strength of concrete.

- Permit the extrapolation of the results for creep compliance in order to obtain values at long-term; and

- Involve mathematical expressions which required to used easily and not sensitive to small variations in the input variables.

\section{B. Strains Identification}

The following equations are used to add the total strain as well as the compliance;

$$
\begin{aligned}
\text { total strain } & =\begin{array}{c}
\text { shrinkage strain }+ \text { compliance } \\
\text { stress }
\end{array} \\
\text { compliance } & =\frac{(\text { elastic strain }+ \text { basic creep }+ \text { drying creep })}{\text { stress }}
\end{aligned}
$$

Test programs for creep and shrinkage are used to determine the total and shrinkage stains from which compliance is 
computed. Thus, the accuracy of the compliance is controlled by the errors within the measure data.

Basic and drying creep are measured from the compliance of the sealed and drying samples by deducting the magnitude of elastic strain. Any errors within the measure elastic strain which is beneficial when calculating the elastic modulus (ASTM C469), or when determining the total strain or shrinkage will be reflected in the computed strain of creep, creep coefficient as well as the magnitude of compliance.

For nondrying samples (sealed), the autogenous shrinkage was ignored when computing the total strain and compliance, hence the equations are simplified to become:

$$
\begin{aligned}
& \text { total stain }=\text { compiance } \times \text { stress } \\
& \text { compliance }=\frac{\text { elastic strain }+ \text { basic creep }}{\text { stress }}
\end{aligned}
$$

\section{Evaluation criteria for creep models}

According to RILEM Committee TC 107 [11], a list of guidelines for assessment of creep and shrinkage models have been published. While the ACI committee 209 [12], during November 1999, has discussed the RILEM criteria and settled the following points:

1. Drying creep and shrinkage must be limited. Their values should not rise considerably with time;

2. Extrapolation is allowed in terms of size and time when equations of creep and shrinkage are used;

3. The predicted models for creep and shrinkage must be validated with RILEM databank restricted by the model conditions of application.

4. The derived equation must be simple to be used and not very sensitive to the variations within the parameters.

5. Good agreement between the individual test results with creep and shrinkage shape of curves over a wide range of time.

6. Compliance as well as specific creep must be used as a comparison with creep values and not the creep coefficient.

7. Drying followed by loading must be accommodated for creep expressions. Many researchers [13] have proved that concrete experience small creep when predried. The impact of pre-drying can also be greatly affected by the size of the sample.

8. Prediction models for creep and shrinkage must be capable to fit concretes with cementitious materials such as silica fume, fly ash slag, natural pozzolans as well as chemical admixtures [14-17];

9. Size of samples effect must be considered in the models;

10. Finally, the models must allow for variations for relative humidity.

\section{SElection OF Models}

Concrete Creep deformation is indeed cause for excessive deflection of service loads that can affect the efficiency of elements inside a structure. Hence, an important prerequisite of the design process is the practical prediction of both the amount and rate of creep strain. While laboratory tests can be carried out to determine the deformation properties of concrete, they are time-consuming, frequently costly, and typically not a realistic choice. To predict the magnitude of creep strain, thus, relatively simple empirically validated national design code models are relied on. This report shows the precision of creep estimations resulted by several commonly international code used, these models don't cover the same materials properties which yields to a wide range of strains prediction. The models addressed are: ACI 209 (1992), Bažant-Baweja B3, CEB MC90, CEB MC9099, GL2000, AS 3600, and BS 8110 (1985).

\section{A. ACI 209R-92 model}

This is the recommended model by ACI committee 209 since 1971 and was established by Branson and Christianson (1971). This model has several advantages which may include [18]:

1. Simple to use which required minimal information, and

2. Ultimate creep can simply be modified to agree with test data of short-term in order to establish best fit for the data.

Its disadvantages involve:

1. Limited accuracy, especially in the way of accommodating the effect of member size when using its simplest formula.

2. It doesn't model the creep phenomena because it is model from empirical data.

This model, at its basic level, requires only:

- concrete age at the beginning of drying, usual considered the same as when moist curing has ended;

- $\quad$ Concrete age at loading;

- Method of curing;

- Relative humidity;

- $\quad$ Average thickness or volume-to-surface (V/S);

- Type of cement.

This model computes creep coefficient and not the compliance, which may lead to uncertainty because of the assumed elastic modulus value.

The following steps are used to compute the compliance by ACI 209R model: 
Compliance $\mathrm{J}\left(\mathrm{t}, \mathrm{t} \_\mathrm{o}\right)=\left(1+\phi\left(\mathrm{t}, \mathrm{t} \_\mathrm{o}\right)\right) / \mathrm{E} \_\mathrm{cmto}$

1. Modulus of elasticity

E_cmto $=0.043 \gamma_{-} \mathrm{c}^{\wedge}(1.5) \sqrt{ }(\mathrm{F}$ cmto $)(\mathrm{MPa})$ in SI units

$F_{-}(\mathrm{cmt})=[\mathrm{t} /(\mathrm{a}+\mathrm{bt})] \mathrm{F}_{-} \mathrm{cm} 28$

Where $a$ and $b$ values are taken from table (1) which depend on cement type and curing method used.

TABLE-1 VALUES FOR A AND B CONSTANTS FOR ACIR-92 MODEL [18]

\begin{tabular}{c|c|c|c|c}
\hline \multirow{2}{*}{$\begin{array}{c}\text { Type of } \\
\text { cement }\end{array}$} & \multicolumn{2}{|c|}{ Moist-cured concrete } & \multicolumn{2}{c}{ Steam-cured concrete } \\
\cline { 2 - 5 } & $\mathrm{a}$ & $\mathrm{b}$ & $\mathrm{a}$ & $\mathrm{b}$ \\
\hline I & 4.0 & 0.85 & 1.0 & 0.95 \\
\hline III & 2.3 & 0.92 & 0.70 & 0.98 \\
\hline
\end{tabular}

\section{Creep coefficient}

$$
\phi\left(\mathrm{t}, \mathrm{t} \_\mathrm{o}\right)=\square\left(\mathrm{t}, \mathrm{t} \_\mathrm{o}\right) \searrow^{\wedge} \Psi /\left(\mathrm{d}+\square\left(\mathrm{t}, \mathrm{t} \_\mathrm{o}\right) \rrbracket \wedge \Psi\right) \phi \_\mathrm{u}
$$

Where $\phi_{-} u=2.35$ for standard conditions, while for other than standard conditions, $\phi_{-} \mathrm{u}=2.35 \gamma \mathrm{c}$

$$
\gamma \mathrm{c}=\gamma \mathrm{c}, \text { to } \gamma \mathrm{c}, \mathrm{RH} \gamma \mathrm{c}, \mathrm{vs} \gamma \mathrm{c}, \mathrm{s} \gamma \mathrm{c}, \psi \gamma \mathrm{c}, \alpha
$$

where $\gamma \mathrm{c}$ is an accumulation product to account for multiple correction factors as follows:

- $\quad \gamma c$,to is a factor which account for load at application of more than 7 days for both moist and steam curing.

- $\gamma \mathrm{c}, \mathrm{to}=1.25 \mathrm{t} \mathrm{o}^{\wedge}(-0.188)$ moist curing

- $\quad \gamma \mathrm{c}$, to $=1.13 \mathrm{t} \mathrm{o}^{\wedge}(-0.094)$ moist curing

- where to represent concrete age at loading in days

- $\quad \gamma c, \mathrm{RH}$ is correction factor to account for relative humidity for ambient

- $\quad \gamma \mathrm{c}, \mathrm{RH}=1.27-0.67 \mathrm{~h}$ for $\mathrm{h} \geqslant 0.40$

- $\gamma c, v s$ is the volume-to-surface (V/S) ratio correction factor which account for member size.

- $\quad \gamma \mathrm{c}, \mathrm{vs}=2 / 3\left(1+1.13 \mathrm{e}^{\wedge}\{-0.0213(\mathrm{~V} / \mathrm{S})\} \quad \ldots\right.$ SI units

- $\quad \gamma c, \psi$ represent a factor or fine aggregate in which $\Psi$ is a ratio of weight fine to total weight aggregate in percentage.

- $\gamma \mathrm{c}, \psi=0.88+0.0024 \Psi$

- $\gamma c, \alpha$ is a factor which accounts for the air content

- $\gamma \mathrm{c}, \alpha=0.46+0.09 \alpha \geqslant 1.0$

Such correction factors for the composition of concrete should only be used in accordance with the suggested average values of $\phi_{-} u=2.35$. The average value of $\phi_{-} u$ must be used in the case when no data are available for specific creep for conditions and local aggregate determined in accordance with ASTM C512.

\section{B. Bažant-Baweja (B3) model}

The Bažant-Baweja (1995) B3 model is the recent version in a series of methods of shrinkage and creep prediction established at Northwestern University by Bažant and his colleagues. Discussing the B3 model and comparing to the other models, Bažant and Baweja conclude that the B3 model is simpler and more highly efficient in a theoretical manner. The key error of this model is the impact of composition of concrete as well as design strength on the model parameters [19].

This model is confined to stress level in the service range about $0.45 \mathrm{fcm} 28$. In addition, these formulas are effective for samples cured for 1 day and more.

The required parameters consist of:

- The concrete age at start of drying, and commonly is starts as soon as moist curing is ends (in days);

- Concrete age at loading (in days);

- Content of aggregate within the concrete $(\mathrm{kg} / \mathrm{m} 3)$;

- The quantity of cement in concrete $(\mathrm{kg} / \mathrm{m} 3)$;

- Quantity of water in concrete $(\mathrm{kg} / \mathrm{m} 3)$;

- Type of cement;

- $\quad$ Average compressive strength of concrete (MPa)

- Concrete modulus of elasticity at 28days (MPa);

- Curing conditions;

- Relative humidity (RH) taken as a decimal;

- Shape of testing specimen;

- The effective cross-sectional thickness or volumeto-surface $(\mathrm{V} / \mathrm{S})$ ratio.

The compliance by B3 model is computed for this equation:

Compliance: $\mathrm{J}\left(\mathrm{t}, \mathrm{t} \_\mathrm{o}\right)=\mathrm{q} \_1+\mathrm{C} \_\mathrm{o}\left(\mathrm{t}, \mathrm{t} \_\mathrm{o}\right)+\mathrm{C} \_\mathrm{d}\left(\mathrm{t}, \mathrm{t} \_\mathrm{o}, \mathrm{t} \_\mathrm{c}\right)$

Where:

q_1 represents an instantaneous strain per unit stress;

C_o $\left(t, t \_o\right)$ basic creep compliance function;

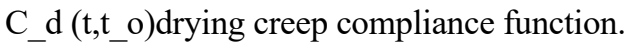

The following steps summarize the main procedures for computing the compliance using B3 model:

1. Elastic strain

$$
\begin{aligned}
& \text { q_1 } 1=0.6 E \_c m 28 \\
& \text { E_cm } 28=4734 \sqrt{ }\left(f \_c m 28\right)
\end{aligned}
$$


2. Basic creep $=$ (aging viscoelastic + non-aging viscoelastic + aging flow) terms

$$
\text { C_o }\left(\mathrm{t}, \mathrm{t} \_\mathrm{o}\right)=\mathrm{q} \_2 \mathrm{Q}\left(\mathrm{t}, \mathrm{t} \_\mathrm{o}\right)+\mathrm{q} \_3 \ln _{2}^{\mathrm{i}} f_{0}\left[1+\left(\mathrm{t}-\mathrm{t} \_\mathrm{o}\right)^{\wedge} \mathrm{n}\right.
$$

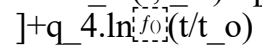

$$
\text { q_ } 2=185.4 \times 10^{\wedge}(-6) \quad \mathrm{c}^{\wedge} 0.5 \quad \text { [f_cm } 28^{\wedge} \nabla \wedge(-0.9)
$$

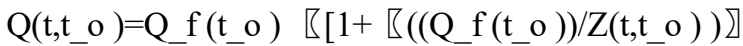

$\wedge\left(\mathrm{r}\left(\mathrm{t} \_\mathrm{o}\right)\right] \bar{\wedge}\left(-1 / \mathrm{r}\left(\mathrm{t} \_\mathrm{o}\right)\right)$

$$
\begin{aligned}
& \text { Q_f (t_o })=\left[0.086\left(t \_o\right)^{\wedge}(2 / 9)+1.21\left(\mathrm{t} \_0\right)^{\wedge}(4 / 9)\right]^{\wedge}(-1) \\
& \mathrm{Z}\left(\mathrm{t}, \mathrm{t} \_\mathrm{o}\right)=\left(\mathrm{t} \_\mathrm{o}\right)^{\wedge}(-\mathrm{m}) \cdot \ln \tilde{z}_{-} \mathrm{f}_{0}\left[1+\left(\mathrm{t}-\mathrm{t} \_\mathrm{o}\right)^{\wedge} \mathrm{n}\right] \\
& \left.\mathrm{r}\left(\mathrm{t} \_\mathrm{o}\right)=1.7 \text { 『(t_o }\right) \rrbracket \wedge 0.12+8 \\
& \text { q_ } 3=0.29 \text { 【(w/c) } \ \wedge 4 \text { 『 } \rrbracket \_2 \\
& \text { q } 4=0.14 \times 10^{\wedge}(-6) \text { 【 }(\mathrm{a} / \mathrm{c}) \rrbracket \wedge(-0.7)
\end{aligned}
$$

Where $\mathrm{c}$ represents the cement quantity in $(\mathrm{kg} / \mathrm{m} 3)$, and the values for $\mathrm{m}$ and $\mathrm{n}$ (empirical parameters) are taken as $(\mathrm{m}=0.5$, and $\mathrm{n}=0.1$ ) for all normal concrete types.

3. Drying creep compliance function $\mathrm{C}_{-} \mathrm{d}\left(\mathrm{t}, \mathrm{t} \mathrm{t}_{-}, \mathrm{t} \_\mathrm{c}\right)$ $\wedge(1 / 2)$

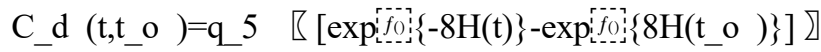

Where q5 represent the compliance parameter for drying creep which is a function of ultimate shrinkage ( $\left.\varepsilon \_s h \infty\right)$ and the mean compressive strength for concrete at 28 days (f_cm28).

$$
\text { q_5 }=0.757 \text { 【f_cm } 28 \rrbracket \wedge(-1) .\left|\varepsilon \_s h \infty \times 10^{\wedge} 6\right|^{\wedge}(-0.6)
$$

$\varepsilon$ sho represent the ultimate shrinkage strain which can be find from the following equations

$$
\begin{aligned}
& \varepsilon \_s h \infty=-\varepsilon_{-} s \infty \times E_{-} c m 607 / E_{-}\left(\mathrm{cm}\left(\mathrm{t}_{-} \mathrm{c}+\tau \text { _ sh }\right)\right) \\
& \varepsilon \_s \infty=-a \_1 \quad a \_2\left[0.019 \mathrm{w}^{\wedge} 2.1 \quad \square \mathrm{f}_{-} \mathrm{cm} 28 \nabla \wedge(-\right. \\
& 0.28)+270] \times 10^{\wedge}(-6)
\end{aligned}
$$

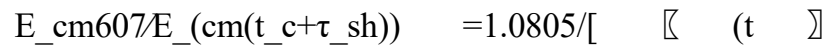

$$
\begin{aligned}
& \left.\left.{ }_{-} \mathrm{c}+\tau_{-} \text {sh }\right) /\left(4+0 . \overline{8} 5\left(\mathrm{t} \_\mathrm{c}+\tau \_\mathrm{sh}\right)\right)\right]^{\wedge} 0.5
\end{aligned}
$$

Where $\varepsilon \_s \infty$ is the nominal ultimate strain, and $a \_1$ [ ,and a $\searrow \_2$ are factors which depend on cement type and curing condition respectively and can be found from tables 2 and 3 .

The pore relative humidity is represented by special averages of $\mathrm{H}(\mathrm{t})$ and $\mathrm{H}(\mathrm{to})$ as shown in equations below;

$$
\begin{aligned}
& \mathrm{H}(\mathrm{t})=1-(1-\mathrm{h}) \cdot \mathrm{S}\left(\mathrm{t}-\mathrm{t} \_\mathrm{c}\right) \\
& \mathrm{H}\left(\mathrm{t} \_\mathrm{o}\right)=1-(1-\mathrm{h}) \cdot \mathrm{S}\left(\mathrm{t} \_\mathrm{o}-\mathrm{t} \_\mathrm{c}\right)
\end{aligned}
$$

$\mathrm{S}\left(\mathrm{t}-\mathrm{t} \_\mathrm{c}\right)$ as well as (t_o-t_c ) represent shrinkage time functions computed for concrete age $t$ and concrete age at loading to respectively, and $\tau_{-}$sh is the half-time shrinkage.

$$
\begin{aligned}
& \left.\mathrm{S}\left(\mathrm{t}-\mathrm{t} \_\mathrm{c}\right)=\tanh \left[\left(\mathrm{t}-\mathrm{t} \_\mathrm{c}\right) / \tau_{-} \operatorname{sh}\right)^{\wedge}(1 / 2)\right] \\
& \mathrm{S}\left(\mathrm{t} \_\mathrm{o}-\mathrm{t} \_\mathrm{c}\right)=\tanh \left[\left(\left(\mathrm{t} \_\mathrm{o}-\mathrm{t} \_\mathrm{c}\right) / \tau \_s h\right)^{\wedge}(1 / 2)\right] \\
& \tau \text { t } \mathrm{sh}=0.085 \text { t_c } \mathrm{c}^{\wedge}(-0.85) \text {. 『f } \mathrm{f} \mathrm{cm} 28 \Omega \wedge(-0.25) \text { 『 }\left[2 \mathrm{k} \_\mathrm{s}\right. \\
& (\mathrm{V} / \mathrm{S})] \bar{\nabla} \wedge 2
\end{aligned}
$$

Where ks represent a correction factor to account for the shape of cross-section which can be taken from table (4), and tc is the beginning of drying age or time when moist curing is ended.

TABLE-2 CEMENT TYPE FACTOR [18]

\begin{tabular}{l|c}
\hline \multicolumn{1}{c|}{ Type of cement } & $\alpha_{1}$ \\
\hline Type I & 1.00 \\
\hline Type II & 0.85 \\
\hline Type III & 1.10 \\
\hline
\end{tabular}

TABLE-3 CURING CONDITION FACTOR[18]

\begin{tabular}{l|c}
\hline \multicolumn{1}{c|}{ Curing method } & $\alpha_{2}$ \\
\hline Steam cured & 0.75 \\
\hline Cured in water or at 100\% relative humidity & 1.00 \\
\hline $\begin{array}{l}\text { Sealed during curing or normal curing in air } \\
\text { with initial protection against drying }\end{array}$ & 1.20 \\
\hline
\end{tabular}

TABLE-4 CROSS-SECTION SHAPE FACTOR[18]

\begin{tabular}{l|c}
\hline \multicolumn{1}{c|}{ Cross section shape } & $k_{s}$ \\
\hline Infinite slab & 1.00 \\
\hline Infinite cylinder & 1.15 \\
\hline Infinite square prism & 1.25 \\
\hline Sphere & 1.30 \\
\hline Cube & 1.55 \\
\hline
\end{tabular}

\section{CEB MC90-99 model}

This model was created by (Muller and Hilsdorf 1990) [18] for prediction the mean cross-sectional time-depended behavior for concrete members. the concept of CEB model is similar to that of ACI 209R-92 model in term of its hyperbolic changes for creep with time. The CEM model does not involve information relating to curing condition or curing duration, however it consider the member size and relative humidity.

The parameters required for this model includes:

- Concrete age at start of drying (days);

- $\quad$ Concrete age at loading (days);

- 28 days mean compressive strength of concrete (MPa) 
- $\quad$ Relative humidity;

- V/S ratio;

- Type of cement.

The following steps summarize the main procedures for computing the compliance using CEB model for stress level of 0.4 of ultimate strength and normal temperatures:

$$
\begin{aligned}
& \mathrm{J}\left(\mathrm{t}, \mathrm{t} \_\mathrm{o}\right)=1 / \mathrm{E} \_\mathrm{cmto}+\left(\phi \_28\left(\mathrm{t}, \mathrm{t} \_\mathrm{o}\right)\right) / \mathrm{E} \_\mathrm{cm} 28 \\
& \text { f_cm } 28=f \_c^{\wedge '}+8.0 \\
& \text { f_cmo }=10 \mathrm{MPa} \\
& \text { E_cmt } \left.28=21500 \sqrt[3]{\left(f \_c m\right.} 28 / \text { f_cmo }\right)
\end{aligned}
$$

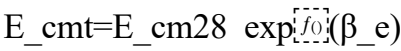

$$
\begin{aligned}
& \beta \_\mathrm{e}=\operatorname{Exp}\left[\mathrm{s} / 2\left(1-\left(28 /\left(\mathrm{t} / \mathrm{t} \_1\right)\right)^{\wedge} 0.5\right]\right.
\end{aligned}
$$

TABLE-5 CEB MC90-99 MODEL-VALUES FOR COEFFICIENT (S) [18]

\begin{tabular}{c|l|c}
\hline \multicolumn{1}{c|}{$f_{c m 28}$} & \multicolumn{1}{|c}{ Type of cement } & \multicolumn{1}{|c}{$s$} \\
\hline \multirow{3}{*}{$\leq 60 \mathrm{MPa}(8700 \mathrm{psi})$} & RS (rapid hardening high-strength cement) & 0.20 \\
\cline { 2 - 3 } & N or R (normal or rapid hardening cements) & 0.25 \\
\cline { 2 - 3 } & SL (slowly-hardening cement) & 0.38 \\
\hline$>60 \mathrm{MPa}(8700 \mathrm{psi})$ & All types & 0.20 \\
\hline
\end{tabular}

1. Elastic compliance is computed form

$$
\begin{aligned}
& \mathrm{J}(\mathrm{t} \text {-o,t_o })=1 / \mathrm{E} \text { cmto } \\
& \text { E_cmto } \left.=f \_c m 28 \times \exp ^{i} f_{0}\right)\left(\beta \_ \text {e }\right)
\end{aligned}
$$

2. Creep coefficient

$$
\begin{aligned}
& \phi \_28\left(\mathrm{t}, \mathrm{t} \_\mathrm{o}\right)=\phi \_0 . \beta \_\mathrm{c}\left(\mathrm{t}, \mathrm{t} \_\mathrm{o}\right) \\
& \text { Notional creep } \phi \_\mathrm{o}=\phi \_\mathrm{RH}(\mathrm{h}) \cdot \beta\left(\mathrm{f} \_\mathrm{cm} 28\right) \cdot \beta\left(\mathrm{t} \_\mathrm{o}\right)
\end{aligned}
$$

With:

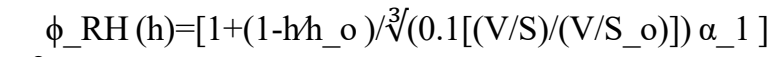

$$
\begin{aligned}
& \text { a_2 } \\
& \beta\left(f \_c m 28\right)=5.3 / \sqrt{ }\left(f \_c m 28 / f \_c m o\right) \\
& \beta\left(\mathrm{t} \_\mathrm{o}\right)=1 /\left(0.1+\left[\left(\mathrm{t} \_\mathrm{o} / \mathrm{t} \_1\right)\right) \wedge 0.2\right) \\
& \alpha \_1=\left[\left(3.5 f \_c m o\right) / f \_c m 28\right]^{\wedge} 0.7 \\
& \alpha \_2=\left[\left(3.5 f \_c m o\right) / f \_c m 28\right]^{\wedge} 0.2
\end{aligned}
$$
1 day.

Where: $\mathrm{f} \_\mathrm{cmo}=10 \mathrm{MPa}, \mathrm{h} \_\mathrm{o}=1, \mathrm{~V} / \mathrm{S} \_\mathrm{o}=50 \mathrm{~mm}$ and $\mathrm{t} \_1=$

$\beta \_c\left(t, t \_o\right)$ coefficient represent the creep development with time taken after loading and is computed as follows:

$$
\beta \_c\left(t, t \_o\right)=\left[\left(\left(t-t \_o\right) / t \_1\right) /\left(\beta \_H+\left(t-t \_o\right) / t \_1\right)\right]^{\wedge} 0.3
$$

With

$\beta \_\mathrm{H}=150\left[1+\left(1.2 \mathrm{hh \_ o}\right)^{\wedge} 18\right](\mathrm{V} / \mathrm{S}) /\left(\mathrm{V} / \mathrm{S} \_\right.$o $)+250 \alpha \_(3) \leqslant$ $1500 \alpha \_(3)$

$$
\text { a_(3) }=\left[\left(3.5 f \_c m o\right) / f \_c m 28\right]^{\wedge} 0.5
$$

With using CEB model one can further consider the effects of curing temperature, cement type, concrete temperature to which concrete is exposed as well as the high stress effect on creep coefficient which were not considered within this report.

\section{GL2000 model}

This model was the last updated version provided by Gardner [20] with minor modifications for some coefficients as well as the time equation for strength development which was originally developed by Gardner and Lockman [21].

To use this model, the parameters required are:

- $\quad$ Concrete age at start of drying (days);

- $\quad$ Concrete age at loading (days);

- 28-days mean compressive strength of concrete $(\mathrm{MPa})$

- $\quad$ Mean compressive strength of concrete at loading (MPa)

- $\quad$ Concrete modulus of elasticity at 28-days (MPa)

- $\quad$ Concrete modulus of elasticity at loading (MPa)

- Relative humidity;

- $\quad \mathrm{V} / \mathrm{S}$ ratio.

To compute the compliance using GL2000 model, the following steps are followed:

1. Compute the mean compressive strength from the following relationship when data from experiments are not valid;

$$
\text { f_cm } 28=1.1 f \_\mathrm{c}^{\wedge^{\prime}}+5.0
$$

2. Modulus of elasticity

$$
\text { E_cmt }=3500+4300 \sqrt{ }(\text { f_cmt })
$$

3. Strength development function with time

$\left.\mathrm{f} \_\mathrm{cmt}=\llbracket \beta \_\mathrm{e}\right] \wedge 2 \mathrm{f}$ cm 28

$\beta_{-} \mathrm{e}=\operatorname{Exp}\left[\mathrm{s} / 2\left(1-(28 / \mathrm{t})^{\wedge} 0.5\right]\right.$

4. Compliance Equations

$$
\mathrm{J}\left(\mathrm{t}, \mathrm{t} \_\mathrm{o}\right)=1 / \mathrm{E} \_\mathrm{cmto}+\left(\phi \_28\left(\mathrm{t}, \mathrm{t} \_\mathrm{o}\right)\right) / \mathrm{E} \_\mathrm{cm} 28
$$

Where: $\phi \_28\left(\mathrm{t}, \mathrm{t} \_\mathrm{o}\right)$ is the creep coefficient which can be computed from the following equation;

$\phi$ _28 (t,t_(o)) $=\Phi\left(\mathrm{t} \_\mathrm{c}\right)\left[\square\left(2 \quad\left(\mathrm{t}-\mathrm{t} \_\mathrm{o}\right)\right)^{\wedge} 0.3 /\left(\left(\mathrm{t}-\mathrm{t} \_\mathrm{o}\right.\right.\right.$ )$\left.^{\wedge} 0.3+14\right)+\left(7 / \mathrm{t} \_\mathrm{o}\right)^{\wedge} 0.5\left(\left(\left(\mathrm{t}-\mathrm{t} \_\mathrm{o}\right)\right) /\left(\left(\mathrm{t}-\mathrm{t} \_\mathrm{o}\right)+\overline{7}\right)\right)^{\wedge} 0.5 @+2.5 \overline{(1-}$ $\left.\left.\left.\left.1.086 \mathrm{~h}^{\wedge} 2\right) \square\left(\left(\left(\mathrm{t}-\mathrm{t} \_\mathrm{o}\right)\right) /\left(\left(\mathrm{t}-\mathrm{t} \_-\mathrm{o}\right)+77 \square(\mathrm{V} / \mathrm{S})\right) \wedge 2\right)\right) \rrbracket \wedge 0.5\right)\right]$ 
As we can see from the creep coefficient which consists of three terms. The first and second term are necessary to compute the basic creep while the third term is to account for drying creep. The correction term $\Phi\left(t_{-} c\right)$ to take the effect of drying before loading.

$$
\begin{aligned}
\text { When } \mathrm{t}_{\mathrm{O}} \mathrm{o}={ }_{-} \mathrm{t} \mathrm{c} \\
\Phi\left(\mathrm{t} \_\mathrm{c}\right)=1.0
\end{aligned}
$$

When $t \_o>t+c$

$$
\begin{aligned}
& \Phi\left(\mathrm{t} \_\mathrm{c}\right)=\left[1-\left(\left(\mathrm{t}-\mathrm{t} \_\mathrm{o}\right)\right) /\left(\left(\mathrm{t}-\mathrm{t} \_\mathrm{o}\right)+0.12 \text { 『(V/S) }\right) \wedge 2\right. \\
& ))^{\wedge} 0.5\right]^{\wedge} 0.5
\end{aligned}
$$

\section{E. British Standard (BS8110-1997)}

The creep of concrete was specified in section 7.3 of BS 8110: Part2: 1997[22]. Concrete creep stain at 30years can be estimated from:

Where:

$$
\varepsilon_{c c}=\frac{\sigma}{E_{t}} \times \phi
$$

$E_{t}$ is the modulus of elasticity for concrete measured at aged of loading t, $\phi$ represent the creep coefficient.

Fig. 1. is used to estimate creep coefficient using BS method in which the effective thickness for the section is equal twice the area of the cross-section divided by perimeter for the exposed uniform section. When drying is prohibited by sealing or water immersion, the effective thickness is taken as $600 \mathrm{~mm}$. The relative humidity available for outdoor and indoor exposures in the UK ranges from the $45 \%$ range to the $85 \%$ range.

The environment in the UK might not be suitable for Iraq. The magnitude concrete can be expected to settle at approximately $40 \%, 60 \%$ and $80 \%$ after a month, 6 months and 30 months, respectively, under constant humidity conditions.

When stress is reduced, a part of the creep is recoverable, it is approximate value can be estimated using BS method after one year:

$$
\text { creep revovery }=\frac{0.3 \times \text { stress reduction }}{E_{u}}
$$

Where

$E_{u}$ is the modulus of elasticity of concrete at age of unloading

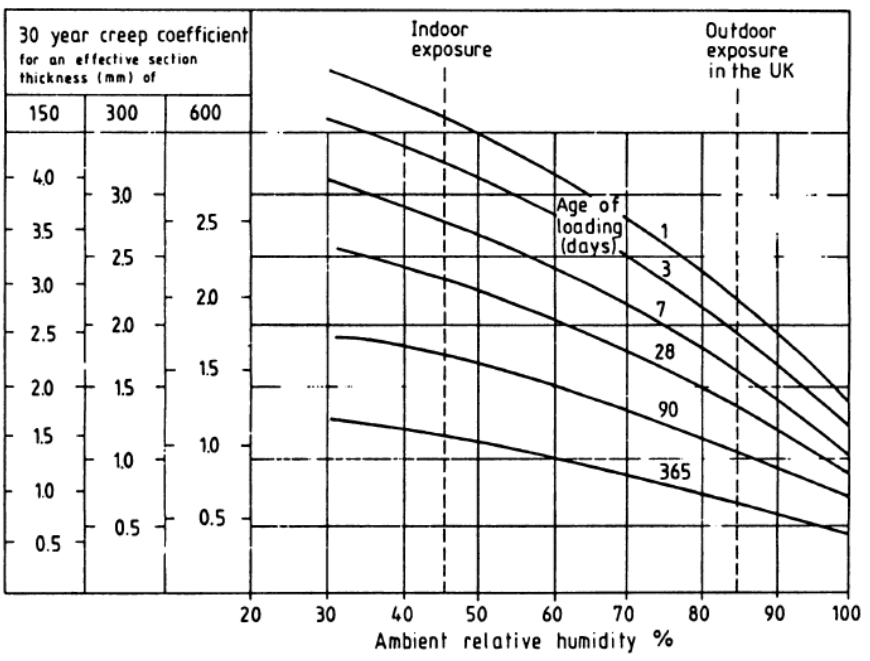

Fig.1. effects of age of loading, section thickness and relative humidity upon the creep factor [22].

\section{F. Australian Standard (AS 3600)}

Creep considerations are specified within the clause (6.1.8.1) of AS 3600[23]. In this method the design creep factor is dependent on the basic creep factor in which they are primarily affected by environment and hardened concrete maturity.

In this method, there are two main steps for computing creep of concrete mainly consist of:

- Coefficient of Basic creep 『( $\left.\phi 】 \_(c c, b)\right)$

Basic creep factor is defined as a ratio of strain of ultimate creep to the elastic strain for samples tested at 28day and loaded under constant stress level of $0.4 \mathrm{f}_{-} \mathrm{c}^{\wedge}$ and is taken from:

I. Values given in Table (6);

II. Measurements on concrete of similar to local;

III. Tests carried out in accordance to AS 1012.16.

TABLE-6 COEFFICIENTS FOR BASIC CREEP [23]

\begin{tabular}{l|c|c|c|c|c|c|c|c}
\hline $\begin{array}{l}\text { Characteri } \\
\text { stic }\end{array}$ & $\mathbf{2}$ & $\mathbf{2}$ & $\mathbf{3}$ & $\mathbf{4}$ & $\mathbf{5}$ & $\mathbf{6}$ & $\mathbf{8}$ & $\mathbf{1 0}$ \\
$\begin{array}{l}\text { strength ( } \\
\left.\boldsymbol{f}_{\mathbf{c}}{ }^{\prime}\right), \text { MPa }\end{array}$ & & $\mathbf{5}$ & $\mathbf{2}$ & $\mathbf{0}$ & $\mathbf{0}$ & $\mathbf{5}$ & $\mathbf{0}$ & $\mathbf{0}$ \\
\hline $\begin{array}{l}\text { Basic creep } \\
\text { coefficient } \\
(\varphi \text { cc.b) }\end{array}$ & 5. & 4. & 3. & 2. & 2. & 2. & 1. & 1. \\
\hline
\end{tabular}

- $\quad$ Coefficient for Design creep $\llbracket\left(\phi{ }_{-}\right.$cc $)$

The design creep factor $\phi \_c c$ is determined from basic creep factor $\phi \_(c c, b)$ at any time $t$ with the help of mathematical model 
of concrete creep behavior, in which they are calibrated in a way that $\phi_{-}$cc is also estimated by choosing the model.

When accurate methods are absent, the following steps can be used to determine $\phi_{-} \mathrm{cc}$ :

$\phi \_c c=k \_2$ k_3 k_4 k_5 k_6 $\phi_{-}(\mathrm{cc}, \mathrm{b})$

Where

k_2 is found from Figure (2);

$\mathrm{k} \_3$ is depended on time at loading $(\tau)$ in days which can be found by from

$\mathrm{k}_{-} 3=2.7 /\left(\left[1+\log _{i} f_{0}(\tau)\right]\right)$ for $\tau \geqslant 1$ day

$\mathrm{k} \_4=0.7$ for arid environments, and 0.5 for the tropical environment or near coastal locations.

$\mathrm{k} \_5=\mathrm{a}$ factor to modify for concrete of high strength, and can be taken as:

k_5 $=1.0$ when $\mathrm{f}_{-} \mathrm{c}^{\wedge} \mathrm{M} \leqslant 50 \mathrm{MPa}$; or

$\mathrm{k} \_5=\left(2-\alpha \_3\right)-0.02\left(1.0-\alpha \_3\right) \mathrm{f} \mathrm{c}^{\wedge \prime}$ when $50 \mathrm{MPa}<\mathrm{f} \mathrm{c}^{\wedge^{\prime}} \leqslant$ $100 \mathrm{MPa}$

$\alpha \_3=0.7 /\left(\mathrm{k} \_4 \quad \alpha \_2\right)$, and $\alpha \_2$ is found from figure (2)

k_6 accounts for sustained loads levels greater that $0.45 \mathrm{f} \_\mathrm{cmi}$;

k_ $6=1.0$ when $\sigma \_0 \leqslant 0.45 f_{-} \mathrm{cmi}$

$\mathrm{k} \_6=\mathrm{e}^{\wedge}\left(1.5\left(\left(\sigma \_\mathrm{o}\right) / \mathrm{f} \_\mathrm{cmi}-0.45\right)\right) \quad$ when $\sigma \_\mathrm{o}>0.45 \mathrm{f} \_\mathrm{cmi}$

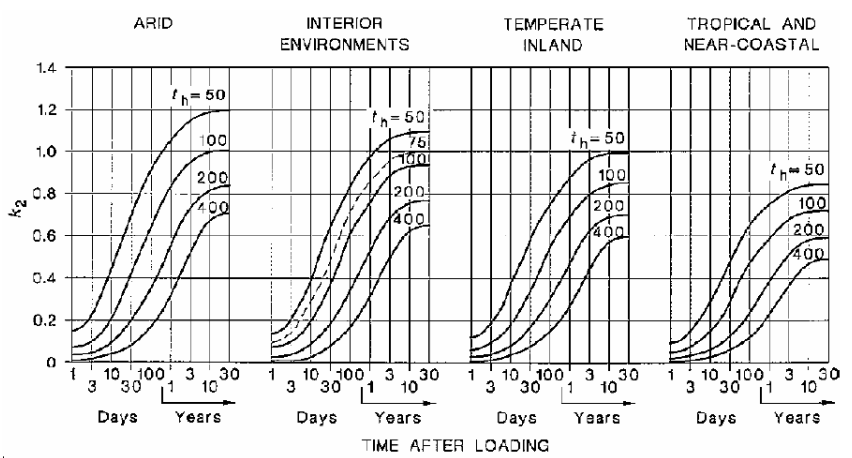

Fig. 2. creep Factor (k2 Coefficient) for different environments [23]

\section{NUMERIC EXAMPLES}

In this section, an example is considered to compute the creep of concrete at different ages. For this purpose and in order to minimize calculation steps and avoid mistakes during computing the different terms; MS Excel is used to compute creep at different times so that the comparison between the models is become simpler.

Example: determine the coefficients for concrete creep strains at ages $(14,28,60,90,180,365,730$, and 1825) days afterward casting process, using the following data: the specified compressive strength of concrete is equal to $25 \mathrm{MPa}$, moist cured for 7days, loading age starts $t_{o}=14$ days, relative humidity $70 \%$, and volume-to-surface ratio $=100 \mathrm{~mm}$.
The problem data can be summarized in the table below:

\begin{tabular}{|c|c|c|}
\hline \multicolumn{3}{|c|}{ Problem data } \\
\hline Concrete data: \\
\hline Specified 28-day strength & $\mathrm{fc}^{\prime}=$ & $25 \mathrm{MPa}$ \\
\hline Ambient conditions: \\
\hline Relative humidity & $\mathrm{h}=$ & 0.7 \\
\hline Temperature & $\mathrm{T}=$ & $20^{\circ} \mathrm{C}$ \\
\hline Specimen: & $\mathrm{V} / \mathrm{S}=$ & $100 \mathrm{~mm}$ \\
\hline Volume-surface ratio & Infinite slab \\
\hline Shape \\
\hline Initial curing: Curing time & $\mathrm{tc}=$ & 7 days \\
\hline Curing condition \\
\hline Concrete at loading: & Moist cured \\
\hline Age at loading & to $=$ & 14 days \\
\hline Applied stress range & $\mathrm{ks}=$ & $40 \%$ \\
\hline
\end{tabular}

Mix design of concrete was done in accordance to ACI 211.1-91[24], for the specified strength ( $\mathrm{fc}^{\prime}=25 \mathrm{MPa}$ ), mix design results are summarized in the table below:

\begin{tabular}{|c|c|c|c|}
\hline \multirow{2}{*}{\multicolumn{2}{|c|}{$\begin{array}{c}\text { Cement type } \\
\text { Maximum aggregate size }\end{array}$}} & \multirow{3}{*}{$\begin{array}{c}\mathrm{I} \\
20 \mathrm{~mm} \\
409 \mathrm{~kg} / \mathrm{m} 3\end{array}$} & \\
\hline & & & \\
\hline Cement content & $\mathrm{c}=$ & & \\
\hline Water content & $\mathrm{w}=$ & $205 \mathrm{~kg} / \mathrm{m} 3$ & $\begin{array}{c}\text { Table 6.3.3 ACI 211.1- } \\
91\end{array}$ \\
\hline Water-cement ratio & $\begin{array}{c}\mathrm{w} / \mathrm{c} \\
=\end{array}$ & 0.50 & \\
\hline Aggregate-cement ratio & $\mathrm{a} / \mathrm{c}=$ & 4.23 & \\
\hline $\begin{array}{l}\text { Fine aggregate } \\
\text { percentage }\end{array}$ & $\psi=$ & $40 \%$ & \\
\hline Air content & $\alpha=$ & $2 \%$ & $\begin{array}{l}\text { Table 6.3.3 ACI 211.1- } \\
91\end{array}$ \\
\hline Slump & $\mathrm{s}=$ & $75 \mathrm{~mm}$ & \\
\hline Unit weight of concrete & $\gamma c=$ & $\begin{array}{c}2345 \\
\mathrm{~kg} / \mathrm{m} 3\end{array}$ & \\
\hline
\end{tabular}

\section{A. ACI 209R-92 model solution}

Excel sheet \#1 summarize the calculation steps for ACI209R-92 model as shown in Table (7) in which the orange cells refers to data need to be entered in order to compute the compliance $\mathrm{J}(\mathrm{t}, \mathrm{to})$ at specified time.

TABLE-7 EXCEL SHEET CALCULATION STEPS BY ACI209R-92 MODEL

\begin{tabular}{|cccc|}
\hline Data & & & \\
1-Concrete Data & & & \\
specified 28--day strength & $\mathrm{fc}^{\prime}=$ & 25 & Mpa \\
Ambient Conditions: & $\mathrm{RH}=$ & 0.7 & \\
& $\mathrm{~T}=$ & 20 & ${ }^{\circ} \mathrm{C}$ \\
\hline
\end{tabular}


Dinkha and Yousif / Journal of Civil Engineering Frontiers Vol. 02, No. 02, pp. 38 -50, (2021)

\begin{tabular}{|c|c|c|c|}
\hline \multirow[t]{2}{*}{ Specimen } & $\mathrm{V} / \mathrm{S}=$ & 100 & \\
\hline & Shape: & \multicolumn{2}{|c|}{ Infinite Slab } \\
\hline \multicolumn{4}{|l|}{ Initial Curing } \\
\hline Curing Time & $\mathrm{tc}=$ & 7 & days \\
\hline Curing Condition & & \multicolumn{2}{|c|}{ Moist Cured } \\
\hline \multicolumn{4}{|l|}{ Concrete at Loading } \\
\hline age at loading & to $=$ & 14 & days \\
\hline applied stress range & ks & $40 \%$ & \\
\hline \multicolumn{4}{|l|}{ Estimate Concrete Properties } \\
\hline mean 28-day strength & $\mathrm{fcm} 28=$ & 33.3 & Mpa \\
\hline Mean 28-day elastic modulus & $\operatorname{Ecm} 28=$ & 28178 & MPa \\
\hline Estimate Concrete Mixture & \multicolumn{3}{|c|}{ mix design summary } \\
\hline Cement Type & & I & \\
\hline Max size of Aggregate & & 20 & $\mathrm{~mm}$ \\
\hline Cement content & $\mathrm{C}=$ & 409 & $\mathrm{~kg} / \mathrm{m} 3$ \\
\hline water content & $\mathrm{w}=$ & 205 & $\mathrm{~kg} / \mathrm{m} 3$ \\
\hline water-cement ratio & $\mathrm{w} / \mathrm{c}=$ & 0.5 & \\
\hline aggregate-cement ratio & $a / c=$ & 4.23 & \\
\hline fine aggregate $\%$ & $y=$ & $40 \%$ & \\
\hline Air Content & $\alpha$ & $2 \%$ & \\
\hline Slump & $\mathrm{s}=$ & 75 & $\mathrm{~mm}$ \\
\hline unit weight of concrete & $\gamma \mathrm{c}=$ & 2345 & $\mathrm{~kg} / \mathrm{m} 3$ \\
\hline
\end{tabular}

\begin{tabular}{|c|c|c|c|}
\hline $\begin{array}{l}\text { Compliance J(t,to) } \\
\text { a) Elastic Compliance } \\
\mathrm{J}(\mathrm{t}, \mathrm{to})\end{array}$ & & & \\
\hline Cement type & $\begin{array}{l}a= \\
b=\end{array}$ & $\begin{array}{c}4 \\
0.85\end{array}$ & \\
\hline Mean Strength at age to & $\begin{array}{c}\mathrm{fcmt} \\
\mathrm{O}=\end{array}$ & 29.3 & $\mathrm{MPa}$ \\
\hline $\begin{array}{c}\text { Mean Elastic Modulus } \\
\text { at age to }\end{array}$ & $\begin{array}{c}\text { Ecmt } \\
0=\end{array}$ & 26441 & $\mathrm{MPa}$ \\
\hline Elastic Compliance & $\begin{array}{c}\mathrm{J}(\mathrm{t}, \mathrm{to} \\
)=\end{array}$ & $\begin{array}{c}3.78 \mathrm{E} \\
-05\end{array}$ & \\
\hline
\end{tabular}

\begin{tabular}{|c|c|c|}
\hline $\begin{array}{l}\text { b) Creep Coefficient } \\
\varnothing(t, t o)\end{array}$ & & \\
\hline $\begin{array}{l}\text { Nominal ultimate creep } \\
\text { coefficient }\end{array}$ & $\varnothing u=$ & 2.35 \\
\hline $\begin{array}{l}\text { Age Application of load } \\
\text { factor }\end{array}$ & $\begin{array}{l}\gamma \mathrm{c}, \text { to } \\
=\end{array}$ & 0.916 \\
\hline Ambient RH factor & $\begin{array}{c}\gamma c, \mathrm{R} \\
\mathrm{H}=\end{array}$ & 0.801 \\
\hline $\mathrm{V} / \mathrm{S}$ & $\begin{array}{l}\gamma \mathrm{c}, \mathrm{vs} \\
=\end{array}$ & 0.756 \\
\hline Slump factor & $\gamma \mathrm{c}, \mathrm{s}=$ & 1.018 \\
\hline
\end{tabular}

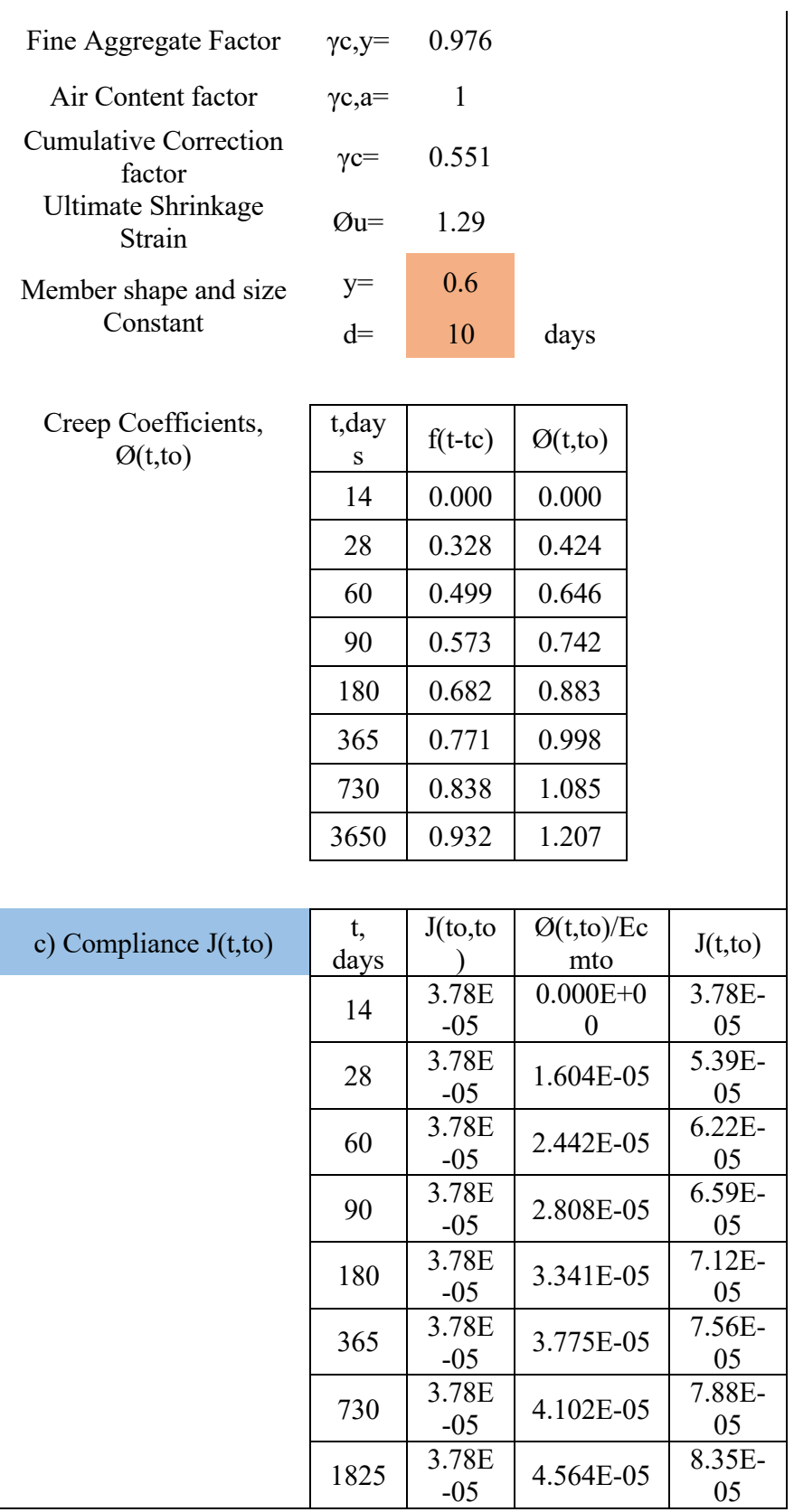

\section{B. Bažant-Baweja B3 model solution}

Excel sheet \#2 summarize the calculation steps for B3 model as shown in Tables (8) in which the orange cells refers to data need to be entered in order to compute the compliance $\mathrm{J}(\mathrm{t}, \mathrm{to})$ at specified time.

TABle-8 ExCel Sheet Calculation STEPS by B3 Model

\begin{tabular}{|cccc|}
\hline Data & & & \\
1-Concrete Data & & & \\
specified 28--day strength & $\mathrm{fc}^{\prime}=$ & 25 & Mpa \\
Ambient Conditions: & $\mathrm{RH}=$ & 0.7 & \\
\hline
\end{tabular}




\begin{tabular}{|c|c|c|c|}
\hline \multirow[t]{2}{*}{ Specimen } & $\begin{array}{c}\mathrm{T}= \\
\mathrm{V} / \mathrm{S}=\end{array}$ & $\begin{array}{c}20 \\
100\end{array}$ & ${ }^{\circ} \mathrm{C}$ \\
\hline & Shape: & \multicolumn{2}{|c|}{ Infinite Slab } \\
\hline \multicolumn{4}{|l|}{ Initial Curing } \\
\hline Curing Time & $\mathrm{tc}=$ & 7 & days \\
\hline Curing Condition & & \multicolumn{2}{|c|}{ Moist Cured } \\
\hline \multicolumn{4}{|l|}{ Concrete at Loading } \\
\hline age at loading & to $=$ & 14 & days \\
\hline applied stress range & ks & $40 \%$ & \\
\hline \multicolumn{4}{|l|}{ Estimate Concrete Properties } \\
\hline mean 28-day strength & $\mathrm{fcm} 28=$ & 33.3 & Mpa \\
\hline Mean 28-day elastic modulus & $\operatorname{Ecm} 28=$ & 27318 & $\mathrm{MPa}$ \\
\hline Estimate Concrete Mixture & \multicolumn{3}{|c|}{ mix design summary } \\
\hline Cement Type & & I & \\
\hline Max size of Aggregate & & 20 & $\mathrm{~mm}$ \\
\hline Cement content & $\mathrm{C}=$ & 409 & $\mathrm{~kg} / \mathrm{m} 3$ \\
\hline water content & $\mathrm{w}=$ & 205 & $\mathrm{~kg} / \mathrm{m} 3$ \\
\hline water-cement ratio & $\mathrm{w} / \mathrm{c}=$ & 0.5 & \\
\hline aggregate-cement ratio & $\mathrm{a} / \mathrm{c}=$ & 4.23 & \\
\hline fine aggregate $\%$ & $y=$ & $40 \%$ & \\
\hline Air Content & $\alpha$ & $2 \%$ & \\
\hline Slump & $\mathrm{s}=$ & 75 & $\mathrm{~mm}$ \\
\hline unit weight of concrete & $\gamma \mathrm{c}=$ & 2345 & $\mathrm{~kg} / \mathrm{m} 3$ \\
\hline
\end{tabular}

\begin{tabular}{|ccc|}
\hline $\begin{array}{c}\text { Compliance } \mathrm{J}(\mathrm{t}, \mathrm{to}) \\
\text { a) Instantaneous } \\
\text { Compliance }\end{array}$ & $q_{1}+C_{o}\left(t, t_{o}\right)+C_{d}\left(t, t_{o}, t_{c}\right)$ \\
\hline
\end{tabular}

b) Compliance function for basic creep

\begin{tabular}{|c|c|c|c|c|}
\hline \multirow[b]{7}{*}{ 1-Aging Viscoelastic term } & $q 2=$ & $1.599 \mathrm{E}-04$ & (1/Mpa) & \\
\hline & Qf(to) $=$ & 0.246 & & \\
\hline & $\mathrm{m}=$ & 0.5 & & \\
\hline & $n=$ & 0.1 & & \\
\hline & $r(t o)=$ & 10.333 & & \\
\hline & $\mathrm{t}$, days & $Z(t, t o)$ & $\mathrm{Q}(\mathrm{t}, \mathrm{to})$ & q2.Q(t,to \\
\hline & 14 & 0.000 & 0 & 0 \\
\hline \multirow{7}{*}{$Q\left(t, t_{o}\right)=Q_{f}\left(t_{o}\right)\left[1+\left(\frac{Q_{f}\left(t_{o}\right)}{Z\left(t, t_{o}\right)}\right)^{r\left(t_{o}\right.}\right]^{-1 / r\left(t_{o}\right)}$} & 28 & 0.223 & 0.216 & $3.458 \mathrm{E}-05$ \\
\hline & 60 & 0.241 & 0.228 & 3.641E-05 \\
\hline & 90 & 0.249 & 0.232 & $3.702 \mathrm{E}-05$ \\
\hline & 180 & 0.262 & 0.236 & $3.778 \mathrm{E}-05$ \\
\hline & 365 & 0.275 & 0.240 & $3.83 \mathrm{E}-05$ \\
\hline & 730 & 0.287 & 0.242 & 3.864E-05 \\
\hline & 1825 & 0.304 & 0.243 & $3.893 \mathrm{E}-05$ \\
\hline
\end{tabular}

\begin{tabular}{|c|c|c|}
\hline \multirow{3}{*}{ 2- Non-Aging Viscoelastic term } & $\mathrm{q} 3=$ & $2.90 \mathrm{E}-06$ \\
& $\mathrm{n}=$ & 0.10 \\
\cline { 2 - 3 } & & \\
\cline { 2 - 3 }$q_{3} \operatorname{tn}\left[1+\left(t-t_{o}\right)^{n}\right]$ & 14 & $q_{3} \ln \left[1+\left(t-t_{0}\right)^{n}\right]$ \\
& 28 & $0.00 \mathrm{E}+00$ \\
& 60 & $2.42 \mathrm{E}-06$ \\
\hline & 90 & $2.62 \mathrm{E}-06$ \\
\hline & 180 & $2.70 \mathrm{E}-06$ \\
\hline & 365 & $2.84 \mathrm{E}-06$ \\
\hline & 730 & $3.11 \mathrm{E}-06$ \\
\hline & 1825 & $3.29 \mathrm{E}-06$ \\
\hline
\end{tabular}

\begin{tabular}{|c|c|c|}
\hline \multirow{10}{*}{$\begin{array}{l}\text { 3- Aging Flow term } \\
q_{4} \cdot \ln \left(\dot{t} / t_{o}\right)\end{array}$} & $q 4=$ & 7.397E-06 \\
\hline & $t$, days & $q_{4} \cdot \ln \left(t / t_{o}\right)$ \\
\hline & 14 & $0.00 \mathrm{E}+00$ \\
\hline & 28 & $5.13 \mathrm{E}-06$ \\
\hline & 60 & $1.08 \mathrm{E}-05$ \\
\hline & 90 & $1.38 \mathrm{E}-05$ \\
\hline & 180 & $1.89 \mathrm{E}-05$ \\
\hline & 365 & $2.41 \mathrm{E}-05$ \\
\hline & 730 & $2.92 \mathrm{E}-05$ \\
\hline & 1825 & $3.60 \mathrm{E}-05$ \\
\hline
\end{tabular}

\begin{tabular}{|c|c|c|c|c|}
\hline \multicolumn{5}{|c|}{ b)Compliance function for basic creep } \\
\hline $\mathrm{t}$, days & $\mathrm{q} 2 . \mathrm{Q}(\mathrm{t}, \mathrm{to})$ & $q_{3} \ln \left[1+\left(t-t_{o}\right)^{n}\right]$ & $q_{4} \cdot \ln \left(\mathrm{t} / t_{o}\right)$ & $C_{o}\left(t, t_{o}\right)$ \\
\hline 14 & $0.00 \mathrm{E}+00$ & $0.00 \mathrm{E}+00$ & $0.00 \mathrm{E}+00$ & $0.00 \mathrm{E}+00$ \\
\hline 28 & $3.46 \mathrm{E}-05$ & $2.42 \mathrm{E}-06$ & $5.13 \mathrm{E}-06$ & $4.213 \mathrm{E}-05$ \\
\hline 60 & $3.64 \mathrm{E}-05$ & $2.62 \mathrm{E}-06$ & $1.08 \mathrm{E}-05$ & $4.979 \mathrm{E}-05$ \\
\hline 90 & $3.70 \mathrm{E}-05$ & $2.70 \mathrm{E}-06$ & $1.38 \mathrm{E}-05$ & $5.349 \mathrm{E}-05$ \\
\hline 180 & $3.78 \mathrm{E}-05$ & $2.84 \mathrm{E}-06$ & $1.89 \mathrm{E}-05$ & $5.951 \mathrm{E}-05$ \\
\hline 365 & $3.83 \mathrm{E}-05$ & $2.98 \mathrm{E}-06$ & $2.41 \mathrm{E}-05$ & $6.540 \mathrm{E}-05$ \\
\hline 730 & $3.86 \mathrm{E}-05$ & $3.11 \mathrm{E}-06$ & $2.92 \mathrm{E}-05$ & $7.100 \mathrm{E}-05$ \\
\hline 1825 & $3.89 \mathrm{E}-05$ & $3.29 \mathrm{E}-06$ & $3.60 \mathrm{E}-05$ & $7.825 \mathrm{E}-05$ \\
\hline
\end{tabular}

\begin{tabular}{|c|c|c|c|}
\hline \multicolumn{4}{|c|}{ c)Compliance function for drying creep } \\
\hline cement type factor & $\alpha_{1}$ & 1 & Table A.7 \\
\hline curing condition factor & $a_{2}$ & 1 & Table A.8 \\
\hline Member Shape Factor & $\mathrm{k}$ & 1 & Table A.9 \\
\hline Nominal Ultimate Shrinkage & $\varepsilon_{s \infty 0}$ & $-7.80 \mathrm{E}-04$ & \\
\hline Shrinkage Halve Time & $\tau_{s h}$ & 1211.323 & \\
\hline \multicolumn{2}{|c|}{ Time Depended Factor $\quad E_{c m 607} / E_{c m\left(t_{c}+\tau_{s h}\right)}$} & 0.998 & \\
\hline \multirow[t]{4}{*}{ Ultimate Shrinkage strain } & $\varepsilon_{\text {shoo }}$ & 7.78E-04 & \\
\hline & $q 5=$ & 4.19E-04 & \\
\hline & $S($ to-tc $)=$ & $7.60 \mathrm{E}-02$ & \\
\hline & $H($ to $)=$ & $9.77 \mathrm{E}-01$ & \\
\hline
\end{tabular}




\begin{tabular}{|c|c|c|c|c|}
\hline $\mathrm{t}$, days & $\mathrm{S}(\mathrm{t}-\mathrm{tc})$ & $\mathrm{H}(\mathrm{t})$ & $\mathrm{f}(\mathrm{H})$ & $\mathrm{Cd}(\mathrm{t}, \mathrm{to}, \mathrm{tc})$ \\
\hline 14 & $7.60 \mathrm{E}-02$ & $9.77 \mathrm{E}-01$ & $0.00 \mathrm{E}+00$ & $0.00 \mathrm{E}+00$ \\
\hline 28 & $1.32 \mathrm{E}-01$ & $9.61 \mathrm{E}-01$ & $7.58 \mathrm{E}-03$ & $3.18 \mathrm{E}-06$ \\
\hline 60 & $2.09 \mathrm{E}-01$ & $9.37 \mathrm{E}-01$ & $1.23 \mathrm{E}-02$ & $5.16 \mathrm{E}-06$ \\
\hline 90 & $2.62 \mathrm{E}-01$ & $9.22 \mathrm{E}-01$ & $1.50 \mathrm{E}-02$ & $6.29 \mathrm{E}-06$ \\
\hline 180 & $3.77 \mathrm{E}-01$ & $8.87 \mathrm{E}-01$ & $2.06 \mathrm{E}-02$ & $8.64 \mathrm{E}-06$ \\
\hline 365 & $5.36 \mathrm{E}-01$ & $8.39 \mathrm{E}-01$ & $2.85 \mathrm{E}-02$ & $1.19 \mathrm{E}-05$ \\
\hline 730 & $7.31 \mathrm{E}-01$ & $7.81 \mathrm{E}-01$ & $3.92 \mathrm{E}-02$ & $1.64 \mathrm{E}-05$ \\
\hline 1825 & $9.51 \mathrm{E}-01$ & $7.15 \mathrm{E}-01$ & $5.37 \mathrm{E}-02$ & $2.25 \mathrm{E}-05$ \\
\hline
\end{tabular}

\begin{tabular}{|c|c|c|}
\hline d)Compliance $\mathrm{J}(\mathrm{t}, \mathrm{to})$ & $\mathrm{t}$, days & $\mathrm{J}(\mathrm{t}, \mathrm{to})$ \\
\hline \multirow{5}{*}{$q_{1}+C_{o}\left(t, t_{o}\right)+C_{d}\left(t, t_{o}, t_{c}\right)$} & 14 & $2.20 \mathrm{E}-05$ \\
\hline \multirow{5}{*}{} & 28 & $6.73 \mathrm{E}-05$ \\
\hline & 60 & $7.69 \mathrm{E}-05$ \\
\hline & 90 & $8.17 \mathrm{E}-05$ \\
\hline & 180 & $9.01 \mathrm{E}-05$ \\
\hline & 365 & $9.93 \mathrm{E}-05$ \\
\hline & 730 & $1.09 \mathrm{E}-04$ \\
\hline & 1825 & $1.23 \mathrm{E}-04$ \\
\hline
\end{tabular}

\section{CEB MC90-99 model solution}

Excel sheet \#3 summarize the calculation steps for CEB MC99 model as shown in Tables (9) in which the orange cells refers to data need to be entered in order to compute the compliance $\mathrm{J}(\mathrm{t}, \mathrm{to})$ at specified time.

TABLe-9 EXCEl SheEt CALCUlation STEPS By CEB MC99 Model

\begin{tabular}{|c|c|c|c|}
\hline Data & & & \\
\hline \multicolumn{4}{|l|}{ 1-Concrete Data } \\
\hline specified 28--day strength & $\mathrm{fc}^{\prime}=$ & 25 & Мра \\
\hline \multirow[t]{2}{*}{ Ambient Conditions: } & $\mathrm{RH}=$ & 0.7 & \\
\hline & $T=$ & 20 & ${ }^{\circ} \mathrm{C}$ \\
\hline \multirow[t]{2}{*}{ Specimen } & $\mathrm{V} / \mathrm{S}=$ & 100 & \\
\hline & Shape: & \multicolumn{2}{|c|}{ Infinite Slab } \\
\hline \multicolumn{4}{|l|}{ Initial Curing } \\
\hline Curing Time & $\mathrm{tc}=$ & 7 & days \\
\hline Curing Condition & & \multicolumn{2}{|c|}{ Moist Cured } \\
\hline \multicolumn{4}{|l|}{ Concrete at Loading } \\
\hline age at loading & to $=$ & 14 & days \\
\hline applied stress range & ks & $40 \%$ & \\
\hline \multicolumn{4}{|l|}{ Estimate Concrete Properties } \\
\hline mean 28-day strength & $\mathrm{fcm} 28=$ & 33 & Mpa \\
\hline strength constant & $\mathrm{fcmo}=$ & 10 & $\mathrm{MPa}$ \\
\hline Mean 28-day elastic modulus & Ecm28= & 32009 & $\mathrm{MPa}$ \\
\hline Estimate Concrete Mixture & \multicolumn{3}{|c|}{ mix design summary } \\
\hline Cement Type & & 1 & \\
\hline Max size of Aggregate & & 20 & $\mathrm{~mm}$ \\
\hline Cement content & $C=$ & 409 & $\mathrm{~kg} / \mathrm{m} 3$ \\
\hline water content & $w=$ & 205 & $\mathrm{~kg} / \mathrm{m} 3$ \\
\hline water-cement ratio & $w / c=$ & 0.5 & \\
\hline aggregate-cement ratio & $a / c=$ & 4.23 & \\
\hline fine aggregate $\%$ & $\mathbf{y}=$ & $40 \%$ & \\
\hline Air Content & a & $2 \%$ & \\
\hline Slump & $s=$ & 75 & $\mathrm{~mm}$ \\
\hline unit weight of concrete & $Y_{c=}$ & 2345 & $\mathrm{~kg} / \mathrm{m} 3$ \\
\hline
\end{tabular}

\begin{tabular}{|c|c|c|c|c|}
\hline \multirow{2}{*}{\multicolumn{5}{|c|}{$\begin{array}{c}\text { Compliance } J(t, t o) \\
\text { a) Elastic Compliance } J(\text { to,to) }\end{array}$}} \\
\hline & & & & \\
\hline \multirow{2}{*}{ Cement type } & $\mathrm{s}$ & 0.25 & Table A.12 & $\mathrm{N}$ \\
\hline & $\beta$ & 0.950 & & \\
\hline Mean Strength at age to & fcmto $=$ & 29.8 & $\mathrm{MPa}$ & \\
\hline Mean Elastic Modulus at age to & Ecmto $=$ & 30394 & $\mathrm{MPa}$ & \\
\hline Elastic Compliance & $J(t, t o)=$ & $3.29 \mathrm{E}-05$ & & \\
\hline \multicolumn{5}{|l|}{ b)Creep Coefficient $\emptyset 28(\mathrm{t}, \mathrm{to})$} \\
\hline \multirow{2}{*}{ compressive strength factor } & $\alpha_{1}$ & 1.042 & & \\
\hline & $\alpha_{2}$ & 1.012 & & \\
\hline \multirow{3}{*}{ bient relative humidity and $\mathrm{V} / \mathrm{S}$ ratio fac } & ho= & 1 & & \\
\hline & $(\mathrm{V} / \mathrm{S})_{0}=$ & 50.000 & & \\
\hline & $\phi_{R H}(h)$ & 2.593 & & \\
\hline Concrete Strength Factor & $\beta\left(f_{\text {em2a }}\right)$ & 2.918 & & \\
\hline adjusted age of loading factor & $\beta\left(t_{0}\right)$ & 0.557 & & \\
\hline Notitonal Creep Factor & $\phi_{o}$ & 4.21 & & \\
\hline \multirow{2}{*}{ Creep coefficient time function } & $\alpha_{3}$ & 1.03 & & \\
\hline & $\beta_{H}$ & 420.47 & & \\
\hline \multirow{9}{*}{ Creep Coefficients, $\varnothing 28(\mathrm{t}, \mathrm{to})$} & $t$,days & $\emptyset 28(t, t o)$ & & \\
\hline & 14 & 0.000 & & \\
\hline & 28 & 0.549 & & \\
\hline & 60 & 0.768 & & \\
\hline & 90 & 0.877 & & \\
\hline & 180 & 1.054 & & \\
\hline & 365 & 1.216 & & \\
\hline & 730 & 1.340 & & \\
\hline & 3650 & 1.490 & & \\
\hline
\end{tabular}

\begin{tabular}{|c|c|c|c|c|}
\hline \multirow{2}{*}{ c)Compliance $\mathrm{J}(\mathrm{t}, \mathrm{to})$} & $\mathrm{t}$, days & $\mathrm{J}(\mathrm{t}, \mathrm{t}, \mathrm{to})$ & $\emptyset(\mathbf{t}, \mathrm{to}) / \mathrm{Ecmto}$ & $\mathrm{J}(\mathrm{t}, \mathrm{to})$ \\
\hline & 14 & $3.29 \mathrm{E}-05$ & $0.000 \mathrm{E}+00$ & $3.29 \mathrm{E}-05$ \\
\hline & 28 & $3.29 \mathrm{E}-05$ & $1.716 \mathrm{E}-05$ & $5.01 \mathrm{E}-05$ \\
\hline & 60 & $3.29 \mathrm{E}-05$ & $2.401 \mathrm{E}-05$ & $5.69 \mathrm{E}-05$ \\
\hline & 90 & $3.29 \mathrm{E}-05$ & $2.739 \mathrm{E}-05$ & $6.03 \mathrm{E}-05$ \\
\hline & 180 & $3.29 \mathrm{E}-05$ & $3.294 \mathrm{E}-05$ & $6.58 \mathrm{E}-05$ \\
\hline & 365 & $3.29 \mathrm{E}-05$ & $3.798 \mathrm{E}-05$ & $7.09 \mathrm{E}-05$ \\
\hline & 730 & $3.29 \mathrm{E}-05$ & $4.188 \mathrm{E}-05$ & $7.48 \mathrm{E}-05$ \\
\hline & 1825 & $3.29 \mathrm{E}-05$ & $4.655 \mathrm{E}-05$ & $7.94 \mathrm{E}-05$ \\
\hline
\end{tabular}

\section{GL2000 model solution}

Excel sheet \#4 summarize the calculation steps for GL2000 model as shown in Tables (10) in which the orange cells refers to data need to be entered in order to compute the compliance $\mathrm{J}(\mathrm{t}, \mathrm{to})$ at a specified time. 
TABLe-10 EXCEl SheEt CALCulation STEPS By GL2000 Model

\begin{tabular}{|c|c|c|c|}
\hline Data & & & \\
\hline \multicolumn{4}{|l|}{ 1-Concrete Data } \\
\hline specified 28--day strength & $\mathrm{fc}^{\prime}=$ & 25 & Mpa \\
\hline \multirow{2}{*}{ Ambient Conditions: } & $\mathrm{RH}=$ & 0.7 & \\
\hline & $\mathrm{T}=$ & 20 & ${ }^{\circ} \mathrm{C}$ \\
\hline \multirow[t]{2}{*}{ Specimen } & $\mathrm{V} / \mathrm{S}=$ & 100 & \\
\hline & Shape: & \multicolumn{2}{|c|}{ Infinite Slab } \\
\hline \multicolumn{4}{|l|}{ Initial Curing } \\
\hline \begin{tabular}{|c|} 
Curing Time \\
\end{tabular} & $\mathrm{tc}=$ & 7 & days \\
\hline Curing Condition & & \multicolumn{2}{|c|}{ Moist Cured } \\
\hline \multicolumn{4}{|l|}{ Concrete at Loading } \\
\hline age at loading & to $=$ & 14 & days \\
\hline applied stress range & ks & $40 \%$ & \\
\hline \multicolumn{4}{|l|}{ Estimate Concrete Properties } \\
\hline mean 28-day strength & $\mathrm{fcm} 28=$ & 32.5 & $\mathrm{MPa}$ \\
\hline Mean 28-day elastic modulus & Ecmt $=$ & 28014 & $\mathrm{MPa}$ \\
\hline Estimate Concrete Mixture & \multicolumn{3}{|c|}{ mix design summary } \\
\hline Cement Type & & 1 & \\
\hline Max size of Aggregate & & 20 & $\mathrm{~mm}$ \\
\hline Cement content & $C=$ & 409 & $\mathrm{~kg} / \mathrm{m} 3$ \\
\hline water content & $w=$ & 205 & $\mathrm{~kg} / \mathrm{m} 3$ \\
\hline water-cement ratio & $w / c=$ & 0.5 & \\
\hline aggregate-cement ratio & $a / c=$ & 4.23 & \\
\hline fine aggregate $\%$ & $\mathbf{y}=$ & $40 \%$ & \\
\hline Air Content & a & $2 \%$ & \\
\hline Slump & $s=$ & 75 & $\mathrm{~mm}$ \\
\hline unit weight of concrete & $Y_{c=}$ & 2345 & $\mathrm{~kg} / \mathrm{m} 3$ \\
\hline \multicolumn{4}{|l|}{ Compliance $\mathrm{J}(\mathrm{t}, \mathrm{to})$} \\
\hline \multicolumn{4}{|l|}{ a) Elastic Compliance $J(t, t o)$} \\
\hline \multirow{3}{*}{ Cement type } & Type & 1 & \\
\hline & $s=$ & 0.335 & TableA.14 \\
\hline & $k=$ & 1 & TableA.14 \\
\hline \multirow{2}{*}{ mean strength at age (to) } & $\beta$ & 0.933 & \\
\hline & $\mathrm{fcmto}=$ & 28.3 & \\
\hline mean elastic modulus at age (to) & Ecmto $=$ & $2.637 E+04$ & \\
\hline Elastic Compliance & $J($ to, to $)=$ & $3.792 \mathrm{E}-05$ & \\
\hline
\end{tabular}

\begin{tabular}{|c|c|c|c|c|c|c|}
\hline \multirow{2}{*}{ b)Creep Coefficient $\emptyset 28(t, t o)$} & \multirow{2}{*}{$t$,days } & \multirow{2}{*}{$\Phi\left(x_{0}\right)$} & \multicolumn{2}{|c|}{ basic creep } & \multirow{2}{*}{$\begin{array}{l}\text { drying } \\
\text { creep }\end{array}$} & \multirow{2}{*}{$\varnothing 28(\mathrm{t}, \mathrm{to})$} \\
\hline & & & Term-1 & Term-2 & & \\
\hline & 14 & 0.9612 & 0.000 & 0.000 & 0 & 0.000 \\
\hline & 28 & 0.9612 & 0.272 & 0.577 & 0.126 & 0.937 \\
\hline & 60 & 0.9612 & 0.368 & 0.659 & 0.225 & 1.203 \\
\hline & 90 & 0.9612 & 0.415 & 0.677 & 0.285 & 1.324 \\
\hline & 180 & 0.9612 & 0.497 & 0.693 & 0.408 & 1.536 \\
\hline & 365 & 0.9612 & 0.586 & 0.700 & 0.556 & 1.771 \\
\hline & 730 & 0.9612 & 0.678 & 0.704 & 0.715 & 2.016 \\
\hline & 3650 & 0.9612 & 0.911 & 0.706 & 1.014 & 2.529 \\
\hline & & & & & & \\
\hline \multirow[t]{9}{*}{ c) Compliance J(t,to) } & $t$, days & $J(t o, t o)$ & \multicolumn{2}{|c|}{$\emptyset(\mathrm{t}, \mathrm{to}) / \mathrm{Ecmto}$} & \multicolumn{2}{|c|}{$\mathrm{J}(\mathrm{t}, \mathrm{to})$} \\
\hline & 14 & $3.79 \mathrm{E}-05$ & \multicolumn{2}{|c|}{$0.000 \mathrm{E}+00$} & \multicolumn{2}{|c|}{ 3.79E-05 } \\
\hline & 28 & $3.79 \mathrm{E}-05$ & \multirow{2}{*}{\multicolumn{2}{|c|}{$3.346 \mathrm{E}-05$}} & \multicolumn{2}{|c|}{$7.14 \mathrm{E}-05$} \\
\hline & 60 & $3.79 \mathrm{E}-05$ & & & \multirow{2}{*}{\multicolumn{2}{|c|}{$\begin{array}{l}8.09 \mathrm{E}-05 \\
8.52 \mathrm{E}-05\end{array}$}} \\
\hline & 90 & $3.79 \mathrm{E}-05$ & \multicolumn{2}{|c|}{$4.725 \mathrm{E}-05$} & & \\
\hline & 180 & 3.79E-05 & \multicolumn{2}{|c|}{ 5.482E-05 } & \multicolumn{2}{|c|}{$9.27 \mathrm{E}-05$} \\
\hline & 365 & $3.79 \mathrm{E}-05$ & \multicolumn{2}{|c|}{$6.322 \mathrm{E}-05$} & \multicolumn{2}{|c|}{$1.01 \mathrm{E}-04$} \\
\hline & 730 & $3.79 \mathrm{E}-05$ & \multicolumn{2}{|c|}{ 7.195E-05 } & \multicolumn{2}{|c|}{$1.10 \mathrm{E}-04$} \\
\hline & 1825 & $3.79 \mathrm{E}-05$ & \multicolumn{2}{|c|}{$9.028 \mathrm{E}-05$} & \multicolumn{2}{|c|}{$1.28 \mathrm{E}-04$} \\
\hline
\end{tabular}

\section{GRAPHICAL COMPARISON OF MODEL PREDICTIONS}

The following figure (Fig. 3.) shows the graphical comparisons of all model predictions.

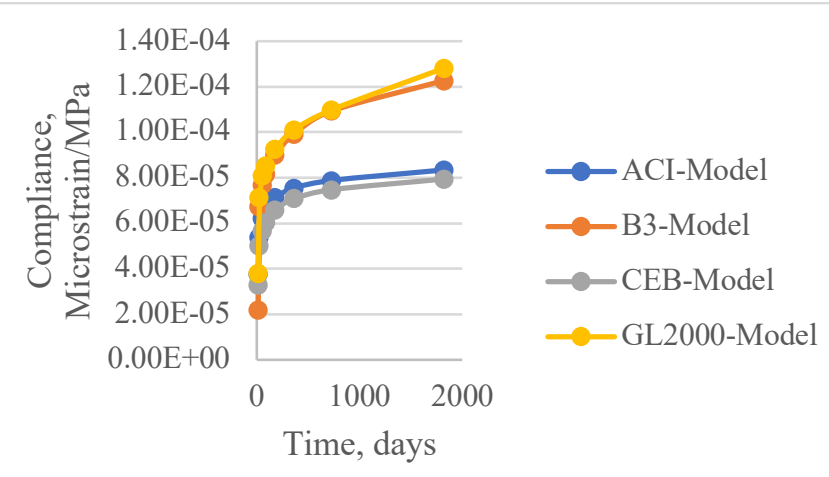

Fig. 3. Comparison between prediction models

\section{REFERENCES}

[1] Fanourakis, G.C. and Y. Ballim. Predicting creep deformation of concrete: a comparison of results from different investigations. in 11 th FIG symposium on deformation measurements. 2003. Santorini Greece.

[2] Bazant, Z.P. and W. Murphy, Creep and shrinkage prediction model for analysis and design of concrete structures-model B3. Matériaux et constructions, 1995. 28(180): p. 357-365.

[3] Alexander, M. and D. Davis, The influence of aggregates on the compressive strength and elastic modulus of concrete. Civil Engineering= Siviele Ingenieurswese, 1992. 34(5): p. 161-170.

[4] Fanourakis, G.C., Evaluation of the creep coefficients of international concrete creep prediction models. 2016.

[5] Mamillan, M. and R. L'Hérmite, Nouveaux résultats de recherches sur la déformation et la rupture du béton. Supplément aux Annales de l'Institut Technique du Bâtiment et des Travaux Publics, 1965(207/208): p. 325345.

[6] McHenry, D. A new aspect of creep in concrete and its application to design. in Proc. ASTM. 1943.

[7] Neville, A.M., Properties of concrete. Vol. 4. 1995: Longman London.

[8] Bazant, Z.P., Theory of creep and shrinkage in concrete structures: A precis of recent developments. Mechanics today, 1975. 2: p. 1-93.

[9] Bazănt, Z., Material models for structural creep analysis. Mathematical modeling of creep and shrinkage of concrete, ed. ZP Bazănt. 1988, John Wiley \& Sons, New York, USA.

[10] Walser, A. and D. Carreira, Analysis of Concrete Containments for NonLinear Strain Gradients. 1979.

[11] DE LA RILEM, C.T., Guidelines for characterizing concrete creep and shrinkage in structural design codes or recommendations. Materials and structures, 1995. 28: p. 52-55.

[12] Videla, C., D.J. Carreira, and N. Garner, Guide for modeling and calculating shrinkage and creep in hardened concrete. ACI report, 2008. 209.

[13] Acker, P. Creep tests of concrete: why and how? in RILEM PROCEEDINGS. 1993. Chapman \& Hall.

[14] Videla, C. and C. Gaedicke, Modeling Portland blast-furnace slag cement high-performance concrete. Materials Journal, 2004. 101(5): p. 365-375.

[15] Videla, C., J.P. Covarrubias, and C. Masana, Updating concrete dryingshrinkage prediction models for local materials. Materials Journal, 2004. 101(3): p. 187-198.

[16] Videla, C. and C. Aguilar, Effectiveness of shrinkage-reducing admixtures on Portland pozzolan cement concrete. Materiales de Construcción, 2005. 55(278): p. 13-28.

[17] Videla, C. and C. Aguilar, Drying shrinkage prediction model for chilean concretes. Revista Ingeniería de Construcción, 2011. 20(2): p. 139-152.

[18] 209-Creep, A.C. and V.C.i. Concrete. Prediction of creep, shrinkage, and temperature effects in concrete structures. 1982. American Concrete Institute. 
[19] Bazant, Z.P. and S. Baweja, Creep and shrinkage prediction model for analysis and design of concrete structures: Model B3. ACI Special Publications, 2000. 194: p. 1-84.

[20] Gardner, N., Comparison of prediction provisions for drying shrinkage and creep of normal-strength concretes. Canadian Journal of Civil Engineering, 2004. 31(5): p. 767-775.

[21] Gardner, N. and M. Lockman, Design provisions for drying shrinkage and creep of normal-strength concrete. Materials journal, 2001. 98(2): p. 159167.
[22] BS, B., Part 1, Code of practice for design and construction, structural use of concrete. London: British Standards Institution, 1997.

[23] AS, A.S., Concrete structures. Standards Australia, Sydney, 2001.

[24] Dixon, D.E., et al., Standard Practice for Selecting Proportions for Normal, Heavyweight, and Mass Concrete (ACI 211.1-91). 1991. 